\title{
Development and validation of highly selective method for the determination of imatinib mesylate and dexketoprofen trometamol combination in three different media
}

\author{
Ozlem Coban $^{1}$, Zelihagul Degim ${ }^{2^{*}}$ \\ ${ }^{1}$ Department of Pharmaceutical Technology, Karadeniz Technical University \\ Faculty of Pharmacy, Trabzon, Turkey, ${ }^{2}$ Department of Pharmaceutical \\ Technology, Biruni University Faculty of Pharmacy, Istanbul, Turkey
}

\begin{abstract}
Imatinib mesylate is a small molecule used in cancer therapy as a thyrosine kinase inhibitor. Dexketoprofen trometamol is a non-steroidal anti-inflammatory drug that has seen use in cancer therapy in combination with an anticancer drug to minimize tumor size and to reduce pain in patients. In the present study, imatinib mesylate and dexketoprofen trometamol were selected as potential model drugs to be used in combination. A new, simple and selective Ultra Performance Liquid Chromatography method was developed and validated to determine the drug substances in distilled water, in a pH 7.4 phosphate buffer and in Dulbecco's Modified Eagle Medium. The proposed method was developed using a BEH C-18 column with isocratic elution. A mixture of methanol:acetonitrile $(80: 20, \mathrm{v} / \mathrm{v})$ and $\mathrm{pH} 9.5,0.05 \mathrm{M}$ ammonium acetate were $(70: 30, \mathrm{v} / \mathrm{v})$ used as a mobile phase. Detection was carried out with a flow rate of $0.3 \mathrm{~mL} / \mathrm{min}$, a column temperature of $30^{\circ} \mathrm{C}$ and an injection volume of $20 \mu \mathrm{L}$. The method was validated considering linearity, accuracy, precision, specificity, robustness, detection limit and quantitation limit values, and was found to be linear in a range from 0.05 to 20.0 $\mu \mathrm{g} / \mathrm{mL}$ for the three different media.
\end{abstract}

Keywords: Imatinib mesylate. Dexketoprofen trometamol. Ultra Performance Liquid Chromatography. Dulbecco's Modified Eagle Medium.

\section{INTRODUCTION}

In pharmacy, toxicology and clinical analysis, the determination or assay of a drug substance has a great importance in terms of increasing productivity and reducing costs. Shortening the analysis time requires shortening column length, increasing flow rate, reducing the particle size of the column and increasing temperature. These approaches, however, come with various risks when applied to HPLC devices. For example, when a short and small particle sized column is used, the compounds in the sample may not always

*Correspondence: Z. Degim, Department of Pharmaceutical Technology, Faculty of Pharmacy, Biruni University, 34010, Istanbul, Turkey. Phone: +905353026845. E-mail: zdegim@gmail.com sufficiently separated, column efficiency may be reduced and high back pressure can be produced (Nováková, Solichová and Solich, 2006). Ultra Performance Liquid Chromatography (UPLC) was developed to overcome all these problems, allowing the separation of small molecules, leading to uniquely superior performance with significant improvements in resolution, sensitivity and speed (Antil et al., 2013). In comparison with the HPLC method, it comes with a reduced analysis time and provides better separation (Gumustas et al., 2013).

Dexketoprofen trometamol (DEX) is a water-soluble salt form of dextrorotatory and an $S(+)$ enantiomer of ketoprofen, which is a non-steroidal anti-inflammatory drug (NSAID). It has been used as a non-selective cyclooxygenase (COX) enzyme inhibitor (Miranda et al., 2011; Herrero et al., 2003). Racemic ketoprofen is also 
used for analgesic and anti-inflammatory effects (Figure 1), although this effect can be observed mainly due to dexketoprofen, as the $R(-)$ enantiomer is not associated with any such activity (Miranda et al., 2011). The free acid form is almost insoluble in water, but soluble in organic solvents such as chloroform, ether and ethanol, while the tromethamine salt is freely soluble in water as well as in organic solvents (Chandrasekharan, 2007).

Imatinib mesylate (IMA) is a potent and selective inhibitor of protein tyrosine kinase Bcr-Alb, plateletderived growth factor and c-KIT (Figure 2). The drug was approved by the FDA for the treatment of chronic mylegeneous leukemia and gastrointestinal stromal tumors in 2001 and 2002 (FDA Consum. 2001; FDA Consum. 2002), respectively. In addition, it has started to be used for the treatment of different types of cancer (Ma, Xu, Shou, 2009; Cohen, Moses, Pazdur, 2002). For example, the dermatofibrosarcoma protuberans, aggressive fibromatoses, malignant melanoma and chordoma forms of cancer have all been treated with IMA (Iqbal, Igbal, 2014). The active ingredient is an off-white to yellowish crystalline powder that is highly soluble in water, although the solubility of the drug is dependent on $\mathrm{pH}$, with solubility decreasing with increasing $\mathrm{pH}$ (Novartis Pharmaceutical Corporation, 2017).

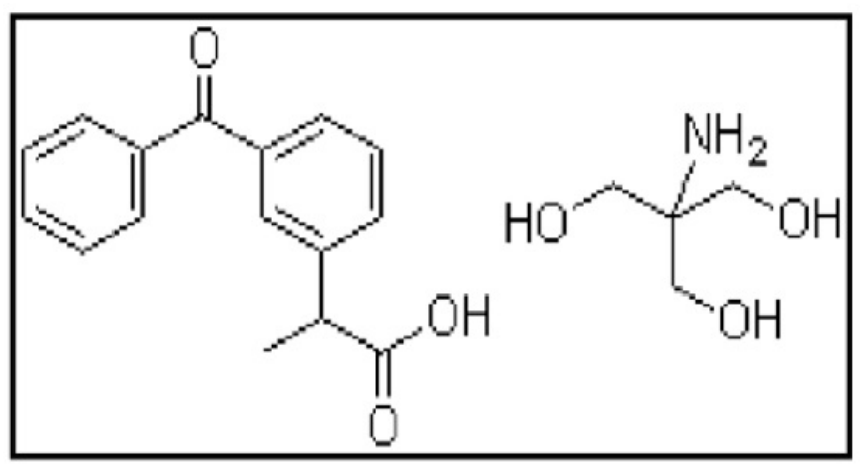

FIGURE 1 - The chemical structure of dexketoprofen trometamol.

Epidemiological studies have indicated that the use of NSAIDs reduces the risk of the development of such fatal cancers as colorectal cancer. Since the COX2 enzyme is responsible for increased prostaglandin production in inflammatory and neoplastic tissues, it continues to affect COX-2 during the treatment of cancer (Dannenberg et al., 2001). It has also been observed that IMA increases COX-2 expression, and as a result, the development of resistance to IMA over time has been reported as possible (Atari-Hajipirloo et al., 2016). Recent studies have shown that the COX enzyme has become a target for the prevention of cancer. Many studies related to the use of combinations of NSAIDs with anticancer drugs can be found in literature as a new approach to the treatment of cancer (Liu et al., 2017; Pan et al., 2007; Mohammed et al., 2003). Due to the positive results obtained from cell culture studies, dosage forms such as liposome and polymeric nanoparticles containing anticancer drug and NSAID in combination have also been developed (Gowda et al., 2017; Singh, 2018).

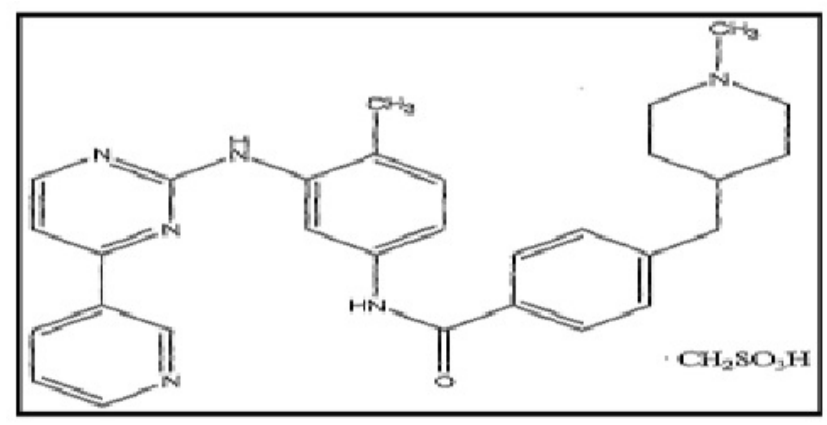

FIGURE 2 - The chemical structure of imatinib mesylate.

Various characterization studies into such topics as encapsulation efficiency, in vitro dissolution rate and ex vivo cell diffusion have been carried out on the developed formulations. The amount of drug in the formulation or releasing the drug to the medium need be calculated (Yue et al., 2009; Miao et al., 2015; Mutlu-A ardan et al., 2016). For this reason, an analytical method specific to the drug should be developed for different media, such as distilled water, a pH 7.4 phosphate buffer, which seen use in dissolution studies, and Dulbecco's Modified Eagle Medium (DMEM), which has been used as a medium in cell culture studies. These media are preferred in the present study due to their recent use in the literature, especially in drug development studies. Distilled water was used as a dissolution medium in in vitro dissolution studies during the formulation development period. The $\mathrm{pH} 7.4$ phosphate buffer is another frequently used dissolution medium. In formulation development studies, cell culture studies are particularly important, and DMEM has been also seen frequent use as a cell culture medium in such studies (Kumari et al., 2018; Reed et al., 2012). In previous literature, many liquid chromatography methods for 
IMA and DEX are available in several media, although there is as yet no chromatographic method for the simultaneous determination of IMA and DEX (Ivanovic et al., 2004; Moreno et al., 2013; Archana, Vikas, 2013; İlbasmış-Tamer, 2017).

Combinations of anticancer drugs and NSAID have proven to be superior to monotherapies, and so there is an apparent need in the future for a proper method of analysis for these drugs in various media in combination for formulation development, quality control or other purposes. IMA has been used in cancer therapy and DEX is a potent NSAID, and it is clear that a combination of the two will be formulated soon. In present study, DEX, which is an NSAID, and IMA, which is an anticancer agent, have been chosen as the model drugs in an attempt to develop a UPLC method for the simultaneous analysis of these drugs in various media. For the present study, three different media were used: distilled water (for encapsulation efficiency), $\mathrm{pH} 7.4$ phosphate buffer (for an in vitro release study) and DMEM (for an ex vivo release study).

\section{MATERIAL AND METHODS}

\section{Material}

Analytical grade methanol $(\geq 99.8 \%$, Sigma, Germany), acetonitrile ( $\geq 99.93 \%$, Sigma, Germany), an ammonium hydroxide solution ( $\geq 25-30 \%$, Sigma, Germany) and ammonium acetate (Merck, Germany) were used in this study for the preparation of the mobile phase. The IMA was supplied by Biotang (USA); the DEX and potassium dihydrogen phosphate (99.995\%) were purchased from Sigma-Aldrich (Germany); the DMEM was supplied from Lonza (Belgium); and the Bi-distilled water was prepared using a Barnstead water purification system (Barnstead, USA).

\section{Analytical and chromatographic conditions}

A UPLC system (Waters Acquity UPLC) with Empower software, equipped with a binary solvent pump, a photo diode array detector and BEH C-18 column $(100 \times 2.1 \mathrm{~mm}, 1.7 \mu \mathrm{m}$ particle size, Acquity, Waters, Ireland) were used. An ultrasonic bath was used for the degassing of the solvent systems. A variety of mobile phases were tested during the development stage of the method for the simultaneous analysis of DEX and IMA. A mixture of methanol:acetonitrile $(80: 20, \mathrm{v} / \mathrm{v})$ and $0.05 \mathrm{M}$ ammonium acetate $(\mathrm{pH} 9.5$ adjusted with ammonium hydroxide) $(70: 30, \mathrm{v} / \mathrm{v})$ was found to be the most suitable mobile phase. The flow rate of the mobile phase and the injection volume of the sample were set to $0.3 \mathrm{~mL} / \mathrm{min}$ and $20 \mu \mathrm{L}$, respectively. The column temperature was maintained at $30{ }^{\circ} \mathrm{C}$. The detection of the drug was carried out at $258 \mathrm{~nm}$ for the distilled water and $\mathrm{pH} 7.4$ phosphate buffer media, and $326 \mathrm{~nm}$ for DMEM. The total run time was 3 minutes.

\section{Preparation of mobile phase, stock solution and samples}

For the preparation of the mobile phase, ammonium acetate $(0.964 \mathrm{~g})$ was dissolved in $250 \mathrm{~mL}$ distilled water in a volumetric flask and the $\mathrm{pH}$ of the solution was adjusted to 9.5 with ammonium hydroxide.

Stock solutions and samples were prepared as follows: DEX (10 mg) and IMA (10 mg) were transferred into volumetric flask and filled up to $100 \mathrm{~mL}$ with distilled water, along with the $\mathrm{pH} 7.4$ phosphate buffer or DMEM. The flask was stirred until all ingredients were dissolved. The final concentration of the stock solution was $100 \mu \mathrm{g} / \mathrm{mL}$. Different volumes of the stock solution were transferred to other $10 \mathrm{~mL}$ volumetric flasks and filled up to the desired volumes with the media. The mobile phase and all other solutions were filtered through a filter paper $(0.22 \mu \mathrm{m}$ pore size $)$ prior to the analysis. In this way, calibration samples were obtained with a concentration range of 0.05 to $20 \mu \mathrm{g} / \mathrm{mL}$. The calibration curves were then obtained by plotting the peak area against the concentration of drug. Each concentration was analyzed in six replicates.

\section{Validation of the analytical method}

The validation studies were carried out based on the International Conference on Harmonisation (ICH) Validation of Analytical Procedures: Text and methodology Q2(R1). The validation parameters, which were indicated in the guideline, were linearity, accuracy, precision (repeatability and intermediate precision), specificity, robustness, detection limit and quantitation limit (ICH, 2005).

\section{RESULTS AND DISCUSSION}

The UPLC proposed in the present study is new, and is appropriate for the simultaneous determination of 
DEX and IMA. The novelty of the method was confirmed through a detailed literature search, which revealed no studies of such a simultaneous determination. The search did, however, reveal some HPLC and UPLC methods for the individual analyses of DEX or IMA in a phoshate buffer or plasma (Rezende, 2013; Sahool, 2015), while no method was identified in literature for DMEM for these substances. For instance, one HPLC method that was successfully validated was found to be useful for the measurement of IMA concentrations in samples from chronic myeloid leukemia patients to check for treatment compliance (Rezende, 2013). Other methods were reported to be useful and being validated in literature for DEX. Although a few sucessfuly validated methods have been published for individual analyses of DEX or IMA, none were found to be directly comparable with the method proposed in the present study (İlbasmış-Tamer, 2017; Mulla, 2011).

\section{Optimization of chromatographic conditions}

To achieve optimal chromatographic separation, different mobile phases and flow rates were tested. Various buffer systems and mobile phases (e.g. potassium dihydrogen phosphate buffers with different molarity, formic acid of different percentages in water or methanol, and various organic solvent systems with different $\mathrm{pH}$ values) were also used to develop the analysis method for IMA and DEX. However, the symmetric and sharp peaks of IMA at the initial part of UPLC method development studies could not obtained. According to the study by Nageswari, Reddy and Mukkanti (2012), reported chromatographic conditions were modified. The proposed method was developed using a BEH C-18 column with isocratic elutions. A mixture of methanol:acetonitrile (80:20, $\mathrm{v} / \mathrm{v}$ ) and $\mathrm{pH} 9.5,0.05 \mathrm{M}$ ammonium acetate was used in a 70:30 v/v ratio as a mobile phase. Various mobile phases were used to obtain a good separation. For example, various buffer systems and mixtures of organic solvents, such as methanol/acetonitrile with water at various ratios, were tested, but the most successful and satisfactory results were obtained with a pH 9.5 acetate buffer. The chromatographic conditions were a flow rate of $0.3 \mathrm{~mL} / \mathrm{min}$, a column temperature of $30{ }^{\circ} \mathrm{C}$ and an injection volume of $20 \mu \mathrm{L}$. As a result, for both IMA and DEX, smooth, sharp and symmetrical peaks were obtained. Validation studies were performed on an Agilent Waters UPLC system with Empower software, and the method was validated according to $\mathrm{ICH}(\mathrm{Q} 2)$ guidelines (linearity, accuracy, precision, specificity and robustness, limit of detection (LOD) and limit of quantification (LOQ) values were calculated).

\section{Parameters of validation}

In line with the method mentioned above, six parallel studies were carried out for IMA and DEX for each medium, with linearity evaluated first. Samples with concentrations ranging from 0.05 to $20 \mu \mathrm{g} / \mathrm{mL}$ were prepared, and the peak area of drug substances corresponding to the concentration of drug substances was plotted (Figure 3, Figure 4 and Figure 5).

The accuracy of a measurement system is defined as the degree of closeness of the measurements to the real value. Samples with known concentrations were analyzed for accuracy with three working level concentrations. Accordingly, 80, 100 and $120 \%$ of the expected concentrations of analyte in the sample was calculated separately for each medium (Table I and Table II).

Precision is related to reproducibility and repeatability, which can be calculated after repeated measurements under unchanging conditions. System precision is evaluated from standard deviation (SD) and relative standard deviation (RSD). Intra-day precision the samples were prepared $(10 \mu \mathrm{g} / \mathrm{mL})$ and injected into system 10 times, while inter-day precision was determined by analyzing the same samples on three different days. The results of the intra-day and inter-day precisions are presented in the tables (Table III, Table IV, Table V and Table VI).

The applied method must detect only the desired drug substance, both specifically and selectively. In a tested formulation, other substances should not give any peak at the same retention time, and this must be checked. The developed method was shown to be specific for IMA and DEX, since the peaks of drug substance were observed on the chromatogram at different retention times (Figure 6, Figure 7 and Figure 8) and no interference was observed from any other substance.

For the developed analytical method, robustness studies should also be performed to ensure that measurements are not affected by minor experimental changes. For example, the stability of analytical solutions, extraction time, $\mathrm{pH}$ value of the mobile phase, mobile phase component ratios or column can be considered 
as minor variations. In this study, the stability of the analytical solutions at various temperatures and times were investigated by calculating the percentage of the remaining DEX and IMA (after 72 hours at 4, 25 and $\left.37{ }^{\circ} \mathrm{C}\right)$. There was no significant differences $\mathrm{p}>0.05$ (Table VII).
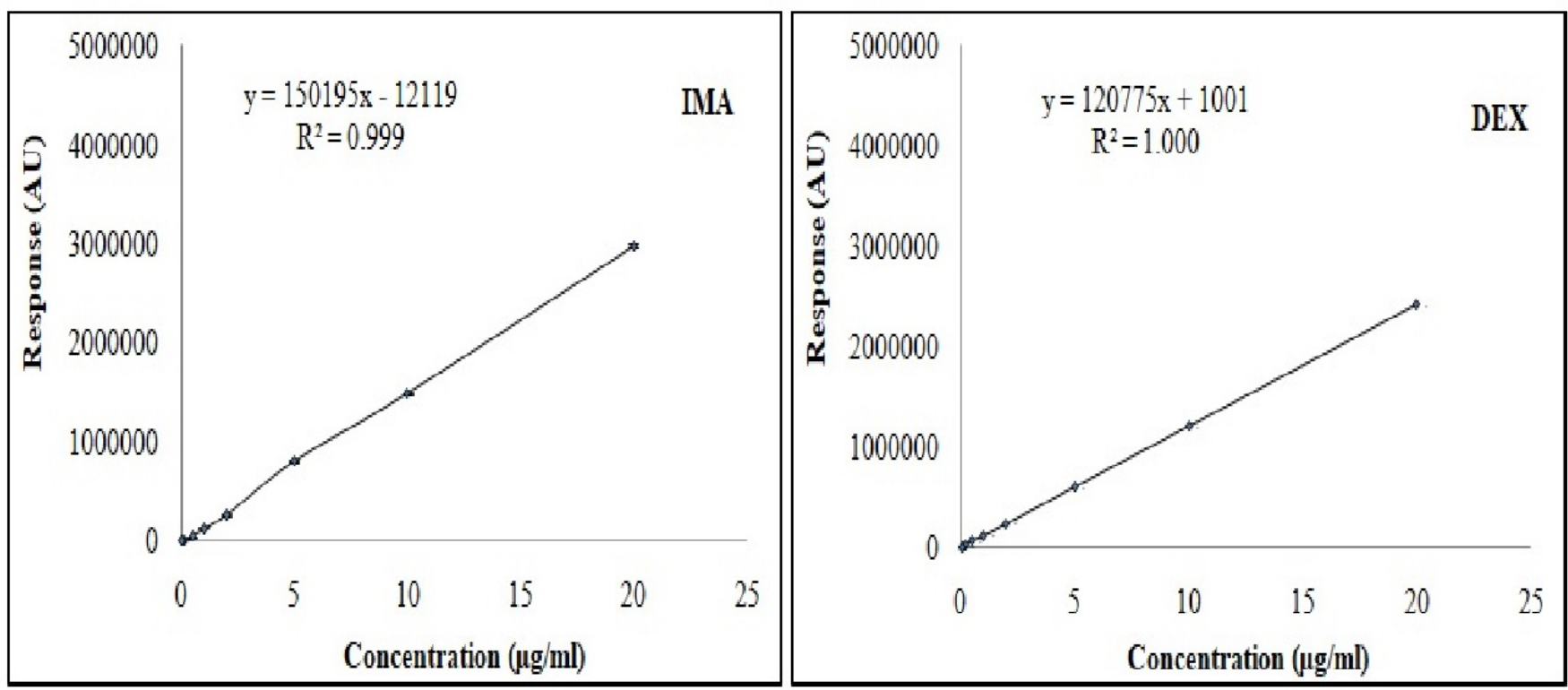

FIGURE 3 - The calibration curves of imatinib mesylate and dexketoprofen trometamol in distilled water $(\mathrm{n}=6)$.
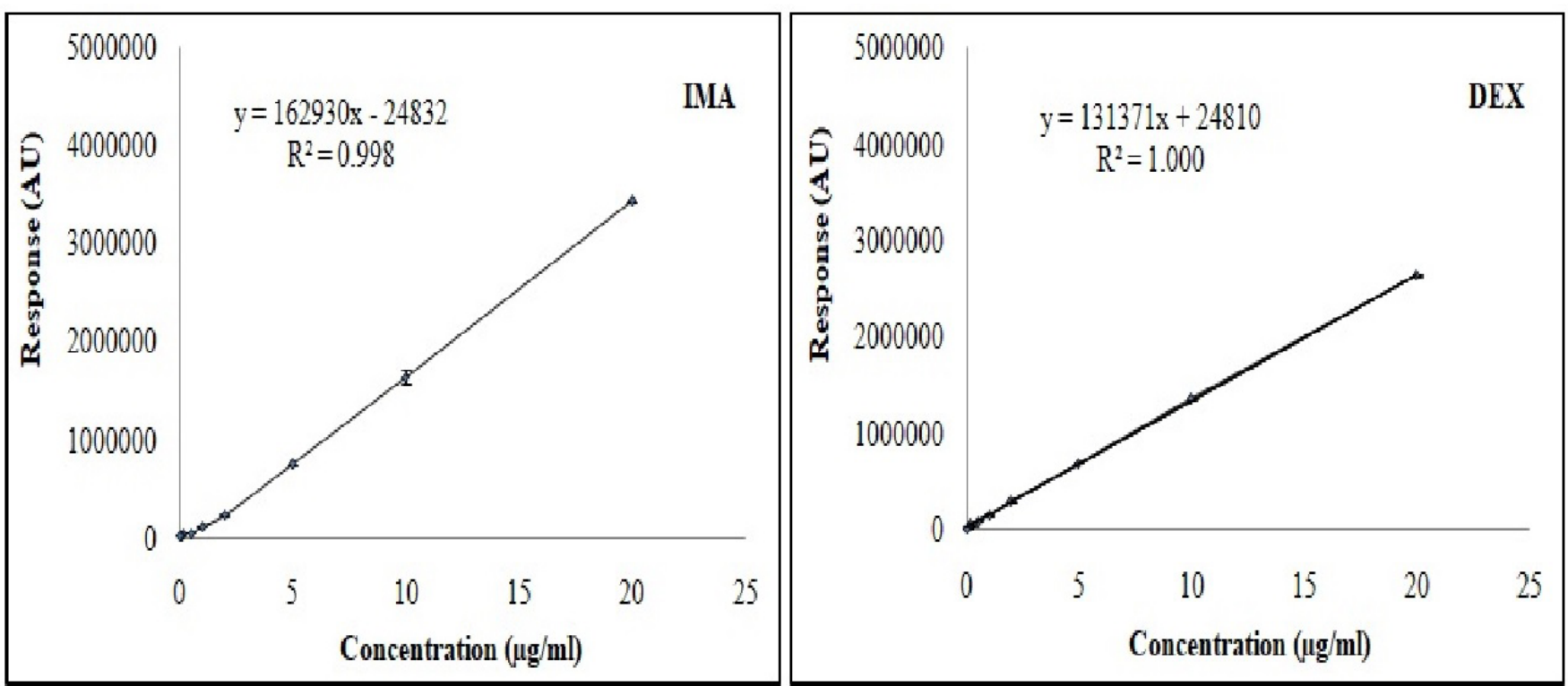

FIGURE 4 - The calibration curves of imatinib mesylate and dexketoprofen trometamol in phosphate buffer ( $\mathrm{n}=6$ ). 

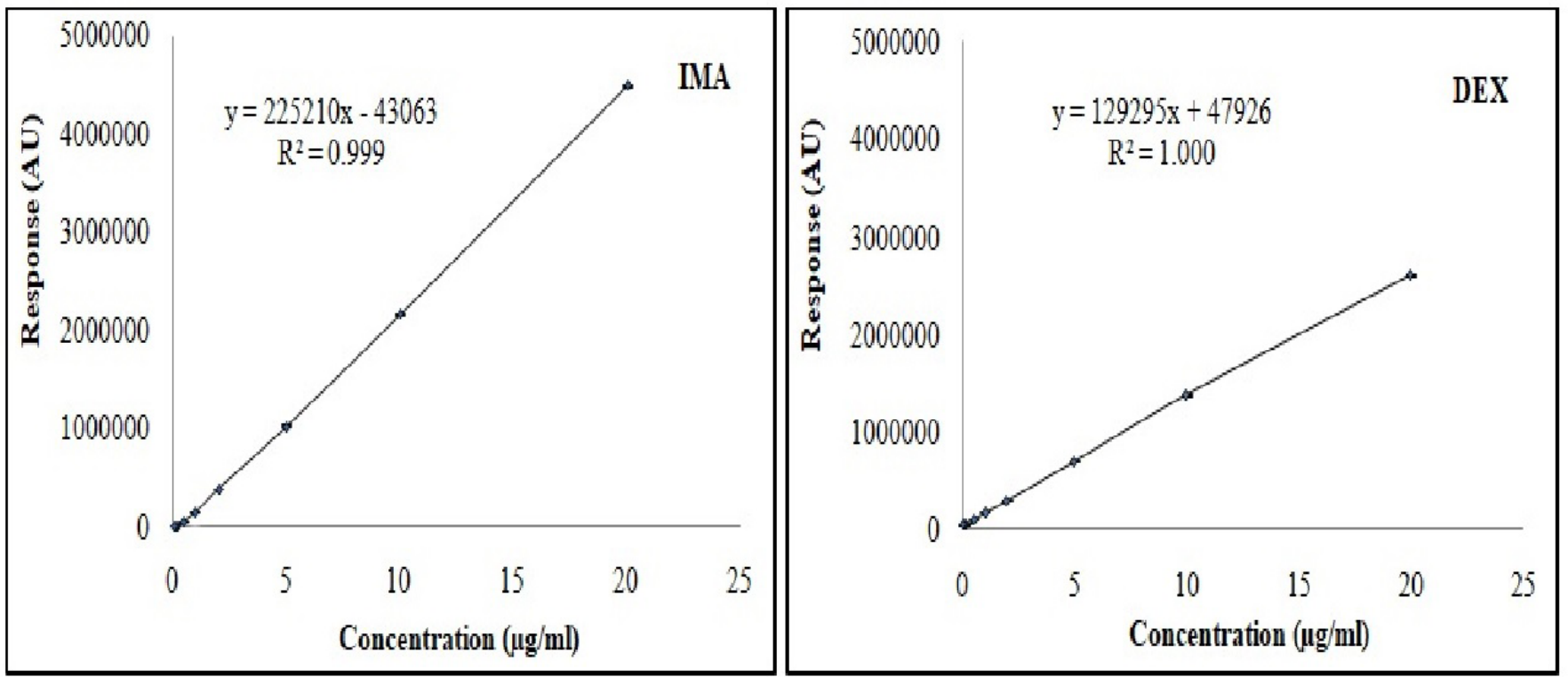

FIGURE 5 - The calibration curves of imatinib mesylate and dexketoprofen trometamol in DMEM $(n=6)$.

TABLE I - Accuracy and recovery report of imatinib mesylate

\begin{tabular}{|c|c|c|c|c|}
\hline & $\begin{array}{c}\text { Percentage level } \\
(\%)\end{array}$ & $\begin{array}{c}\text { Concentration of IMA in } \\
\text { solution } \\
(\mu \mathrm{g} / \mathrm{mL})\end{array}$ & 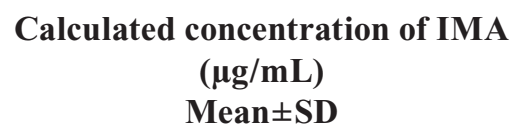 & RSD\% \\
\hline \multirow{3}{*}{ Distilled water } & 120 & 12 & $12.100 \pm 0.029$ & 0.239 \\
\hline & 100 & 10 & $10.040 \pm 0.006$ & 0.058 \\
\hline & 80 & 8 & $8.140 \pm 0.031$ & 0.386 \\
\hline \multirow[b]{2}{*}{ pH 7.4 Phosphate Buffer } & 120 & 12 & $12.434 \pm 0.077$ & 0.619 \\
\hline & 100 & 10 & $10.291 \pm 0.027$ & 0.263 \\
\hline \multirow{3}{*}{ DMEM } & 120 & 12 & $12.004 \pm 0.050$ & 0.414 \\
\hline & 100 & 10 & $9.999 \pm 0.002$ & 0.021 \\
\hline & 80 & 8 & $7.998 \pm 0.019$ & 0.236 \\
\hline
\end{tabular}

IMA is imatinib mesylate. Conc. is concentration. DMEM is Dulbecco's Modified Eagle Medium. SD is standard deviation and RSD is relative standard deviation $(n=3)$. 
TABLE II - Accuracy and recovery report of dexketoprofen trometamol

\begin{tabular}{lcccc}
\hline & $\begin{array}{c}\text { Percentage level } \\
(\mathbf{\%})\end{array}$ & $\begin{array}{c}\text { Concentration of DEX } \\
\text { in solution }(\boldsymbol{\mu g} / \mathbf{m L})\end{array}$ & $\begin{array}{c}\text { Calculated concentration } \\
\text { of DEX }(\boldsymbol{\mu g} / \mathbf{m L}) \\
\text { Mean } \pm \text { SD }\end{array}$ & RSD\% \\
\hline & 120 & 12 & $11.911 \pm 0.007$ & 0.061 \\
Distilled water & 100 & 10 & $10.012 \pm 0.014$ & 0.136 \\
& 80 & 8 & $8.032 \pm 0.007$ & 0.090 \\
\hline pH 7.4 Phosphate & 120 & 12 & $12.213 \pm 0.015$ & 0.120 \\
Buffer & 100 & 10 & $10.071 \pm 0.007$ & 0.071 \\
& 80 & 8 & $7.932 \pm 0.004$ & 0.050 \\
\hline DMEM & 120 & 12 & $12.263 \pm 0.093$ & 0.757 \\
& 100 & 10 & $10.166 \pm 0.080$ & 0.785 \\
\hline
\end{tabular}

DEX is dexketoprofen trometamol. Conc. is concentration. DMEM is Dulbecco's Modified Eagle Medium. SD is standard deviation and RSD is relative standard deviation $(n=3)$.

TABLE III - Intra-day precision for imatinib mesylate

\begin{tabular}{|c|c|c|c|c|c|}
\hline \multicolumn{2}{|c|}{ Distilled water } & \multicolumn{2}{|c|}{ pH 7.4 Phosphate Buffer } & \multicolumn{2}{|c|}{ DMEM } \\
\hline $\begin{array}{l}\text { Concentration } \\
(\mu \mathrm{g} / \mathrm{mL})\end{array}$ & Analyzed Value & $\begin{array}{c}\text { Concentration } \\
(\mu \mathrm{g} / \mathrm{mL})\end{array}$ & Analyzed Value & $\begin{array}{c}\text { Concentration } \\
(\mu \mathrm{g} / \mathrm{mL})\end{array}$ & Analyzed Value \\
\hline 20 & 20.067 & 20 & 20.159 & 20 & 19.949 \\
\hline 20 & 20.088 & 20 & 20.120 & 20 & 19.951 \\
\hline 20 & 20.020 & 20 & 20.129 & 20 & 19.949 \\
\hline 20 & 20.090 & 20 & 20.127 & 20 & 19.948 \\
\hline 20 & 20.014 & 20 & 20.139 & 20 & 19.946 \\
\hline 20 & 20.029 & 20 & 20.124 & 20 & 19.943 \\
\hline 20 & 20.010 & 20 & 20.133 & 20 & 19.934 \\
\hline 20 & 20.088 & 20 & 20.130 & 20 & 19.943 \\
\hline
\end{tabular}


TABLE III - Intra-day precision for imatinib mesylate

\begin{tabular}{|c|c|c|c|c|c|}
\hline \multicolumn{2}{|c|}{ Distilled water } & \multicolumn{2}{|c|}{ pH 7.4 Phosphate Buffer } & \multicolumn{2}{|c|}{ DMEM } \\
\hline $\begin{array}{l}\text { Concentration } \\
(\mu \mathrm{g} / \mathrm{mL})\end{array}$ & Analyzed Value & $\begin{array}{c}\text { Concentration } \\
(\mu \mathrm{g} / \mathrm{mL})\end{array}$ & Analyzed Value & $\begin{array}{c}\text { Concentration } \\
(\mu \mathrm{g} / \mathrm{mL})\end{array}$ & Analyzed Value \\
\hline 20 & 20.013 & 20 & 20.095 & 20 & 19.926 \\
\hline 20 & 20.071 & 20 & 20.028 & 20 & 19.914 \\
\hline Mean & 20.049 & Mean & 20.118 & Mean & 19.940 \\
\hline SD & 0.202 & SD & 0.036 & SD & 0.120 \\
\hline $\mathrm{RSD} \%$ & 0.981 & $\mathrm{RSD} \%$ & 0.177 & $\mathrm{RSD} \%$ & 0.619 \\
\hline
\end{tabular}

DMEM is Dulbecco's Modified Eagle Medium. SD is standard deviation and RSD is relative standard deviation ( $\mathrm{n}=10)$.

TABLE IV - Intra-day precision for dexketoprofen trometamol

\begin{tabular}{|c|c|c|c|c|c|}
\hline \multicolumn{2}{|c|}{ Distilled water } & \multicolumn{2}{|c|}{ pH 7.4 Phosphate Buffer } & \multicolumn{2}{|c|}{ DMEM } \\
\hline $\begin{array}{l}\text { Concentration } \\
(\mu \mathrm{g} / \mathrm{mL})\end{array}$ & Analyzed Value & $\begin{array}{c}\text { Concentration } \\
(\mu \mathrm{g} / \mathrm{mL})\end{array}$ & Analyzed Value & $\begin{array}{c}\text { Concentration } \\
(\mu \mathrm{g} / \mathrm{mL})\end{array}$ & $\begin{array}{c}\text { Analyzed } \\
\text { Value }\end{array}$ \\
\hline 10 & 10.011 & 10 & 10.135 & 10 & 10.445 \\
\hline 10 & 10.021 & 10 & 10.128 & 10 & 10.448 \\
\hline 10 & 10.034 & 10 & 10.125 & 10 & 10.433 \\
\hline 10 & 10.027 & 10 & 10.124 & 10 & 10.433 \\
\hline 10 & 10.018 & 10 & 10.143 & 10 & 10.426 \\
\hline 10 & 10.033 & 10 & 10.127 & 10 & 10.420 \\
\hline 10 & 10.036 & 10 & 10.135 & 10 & 10.407 \\
\hline 10 & 10.040 & 10 & 10.141 & 10 & 10.397 \\
\hline 10 & 10.048 & 10 & 10.136 & 10 & 10.394 \\
\hline 10 & 10.038 & 10 & 10.136 & 10 & 10.386 \\
\hline Mean & 10.031 & Mean & 10.133 & Mean & 10.419 \\
\hline SD & 0.011 & SD & 0.007 & SD & 0.022 \\
\hline $\mathrm{RSD} \%$ & 0.112 & RSD $\%$ & 0.066 & RSD $\%$ & 0.216 \\
\hline
\end{tabular}

DMEM is Dulbecco's Modified Eagle Medium. SD is standard deviation and RSD is relative standard deviation ( $\mathrm{n}=10)$. 
TABLE V - Inter-day precision for imatinib mesylate

\begin{tabular}{|c|c|c|c|c|c|c|c|}
\hline & $\begin{array}{c}\text { Concentration } \\
(\mu \mathrm{g} / \mathrm{mL})\end{array}$ & 1.day & 2. day & 3. day & Mean & SD & RSD\% \\
\hline \multirow{4}{*}{ Distilled water } & 20 & 19.977 & 19.975 & 19.968 & 19.974 & 0.047 & 0.239 \\
\hline & 5 & 5.015 & 5.014 & $5 . .004$ & 5.011 & 0.059 & 1.147 \\
\hline & 1 & 0.994 & 0.996 & 0.996 & 0.996 & 0.010 & 1.069 \\
\hline & 0.2 & 0.196 & 0.196 & 0.196 & 0.196 & 0.001 & 0.923 \\
\hline \multirow{4}{*}{$\begin{array}{l}\text { pH } 7.4 \text { Phosphate } \\
\text { Buffer }\end{array}$} & 20 & 19.964 & 20.069 & 19.899 & 19.977 & 0.086 & 0.430 \\
\hline & 5 & 4.834 & 4.900 & 4.929 & 4.888 & 0.049 & 0.993 \\
\hline & 1 & 0.944 & 0.945 & 0.924 & 0.938 & 0.012 & 1.275 \\
\hline & 0.2 & 0.216 & 0.221 & 0.218 & 0.218 & 0.003 & 1.266 \\
\hline \multirow{4}{*}{ DMEM } & 20 & 20.019 & 20.019 & 20.023 & 20.020 & 0.026 & 0.127 \\
\hline & 5 & 4.979 & 4.979 & 4.978 & 4.979 & 0.001 & 0.107 \\
\hline & 1 & 0.997 & 0.997 & 0.997 & 0.997 & 0.001 & 0.156 \\
\hline & 0.2 & 0.204 & 0.204 & 0.204 & 0.204 & 0.002 & 0.098 \\
\hline
\end{tabular}

DMEM is Dulbecco's Modified Eagle Medium. SD is standard deviation and RSD is relative standard deviation $(\mathrm{n}=3)$.

TABLE VI - Inter-day precision for dexketoprofen trometamol

\begin{tabular}{lccccccc}
\hline & $\begin{array}{c}\text { Concentration } \\
(\mu \mathbf{g} / \mathbf{m L})\end{array}$ & 1.day & 2.day & 3. day & Mean & SD & RSD\% \\
\hline & 10 & 10.034 & 10.046 & 10.024 & 10.035 & 0.011 & 0.110 \\
& 2 & 1.963 & 1.965 & 1.963 & 1.964 & 0.001 & 0.065 \\
Distilled water & 0.5 & 0.487 & 0.487 & 0.488 & 0.487 & 0.001 & 0.185 \\
& 0.09 & 0.087 & 0.087 & 0.086 & 0.087 & 0.000 & 0.381 \\
& 10 & 9.947 & 9.890 & 9.840 & 9.892 & 0.053 & 0.541 \\
pH 7.4 Phosphate & 2 & 2.018 & 2.004 & 2.011 & 2.011 & 0.007 & 0.358 \\
Buffer & 0.5 & 0.499 & 0.503 & 0.496 & 0.499 & 0.004 & 0.713 \\
& 0.1 & 0.094 & 0.094 & 0.093 & 0.093 & 0.001 & 0.804 \\
\hline
\end{tabular}


TABLE VI - Inter-day precision for dexketoprofen trometamol

\begin{tabular}{cccccccc}
\hline & $\begin{array}{c}\text { Concentration } \\
(\boldsymbol{\mu g} / \mathbf{m L})\end{array}$ & 1.day & 2. day & 3. day & Mean & SD & RSD\% \\
\hline & 10 & 10.254 & 10.263 & 10.085 & 10.201 & 0.100 & 0.984 \\
DMEM & 2 & 1.984 & 2.024 & 2.002 & 2.004 & 0.020 & 0.999 \\
& 0.5 & 0.465 & 0.468 & 0.477 & 0.470 & 0.006 & 1.306 \\
& 0.05 & 0.051 & 0.051 & 0.051 & 0.051 & 0.000 & 0.821 \\
\hline
\end{tabular}

DMEM is Dulbecco's Modified Eagle Medium. SD is standard deviation and RSD is relative standard deviation $(\mathrm{n}=3)$.

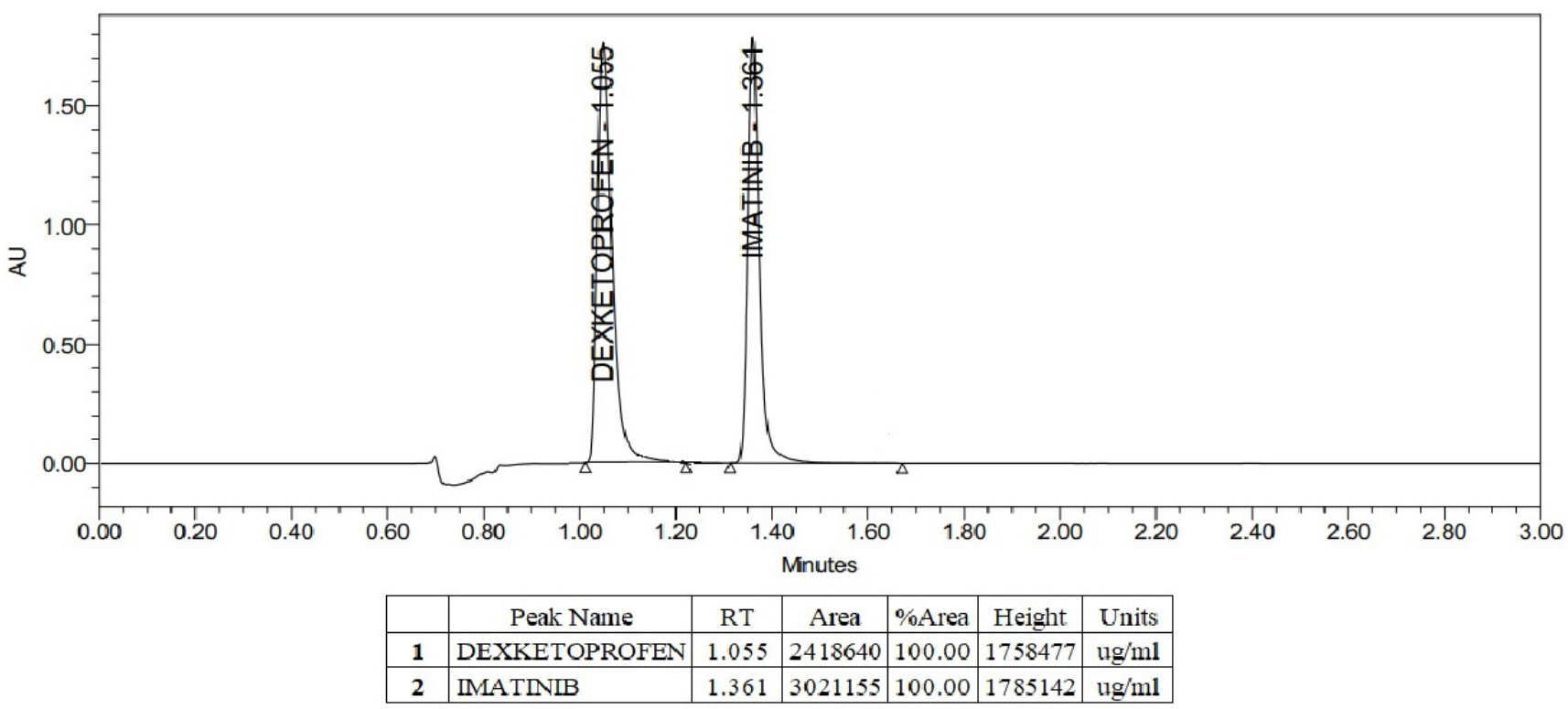

FIGURE 6 - UPLC chromatogram of dexketoprofen trometamol and imatinib mesylate in distilled water. 


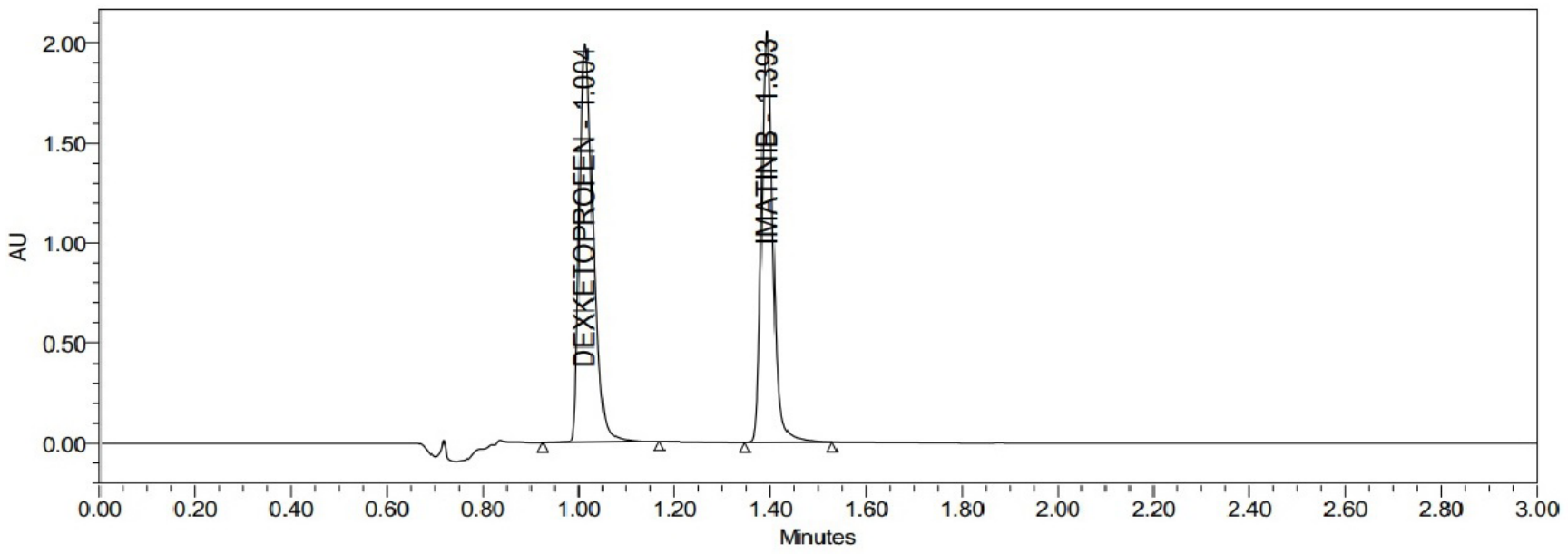

\begin{tabular}{|c|l|c|c|c|c|c|}
\hline & \multicolumn{1}{|c|}{ Peak Name } & RT & Area & \%Area & Height & Units \\
\hline $\mathbf{1}$ & DEXKETOPROFEN & $\mathbf{1 . 0 0 4}$ & 2639684 & 100.00 & 1936308 & $\mathrm{ug} / \mathrm{ml}$ \\
\hline 2 & IMATINIB & 1.393 & 3448071 & 100.00 & 2057061 & $\mathrm{ug} / \mathrm{ml}$ \\
\hline
\end{tabular}

FIGURE 7 - UPLC chromatogram of dexketoprofen trometamol and imatinib mesylate in phosphate buffer.

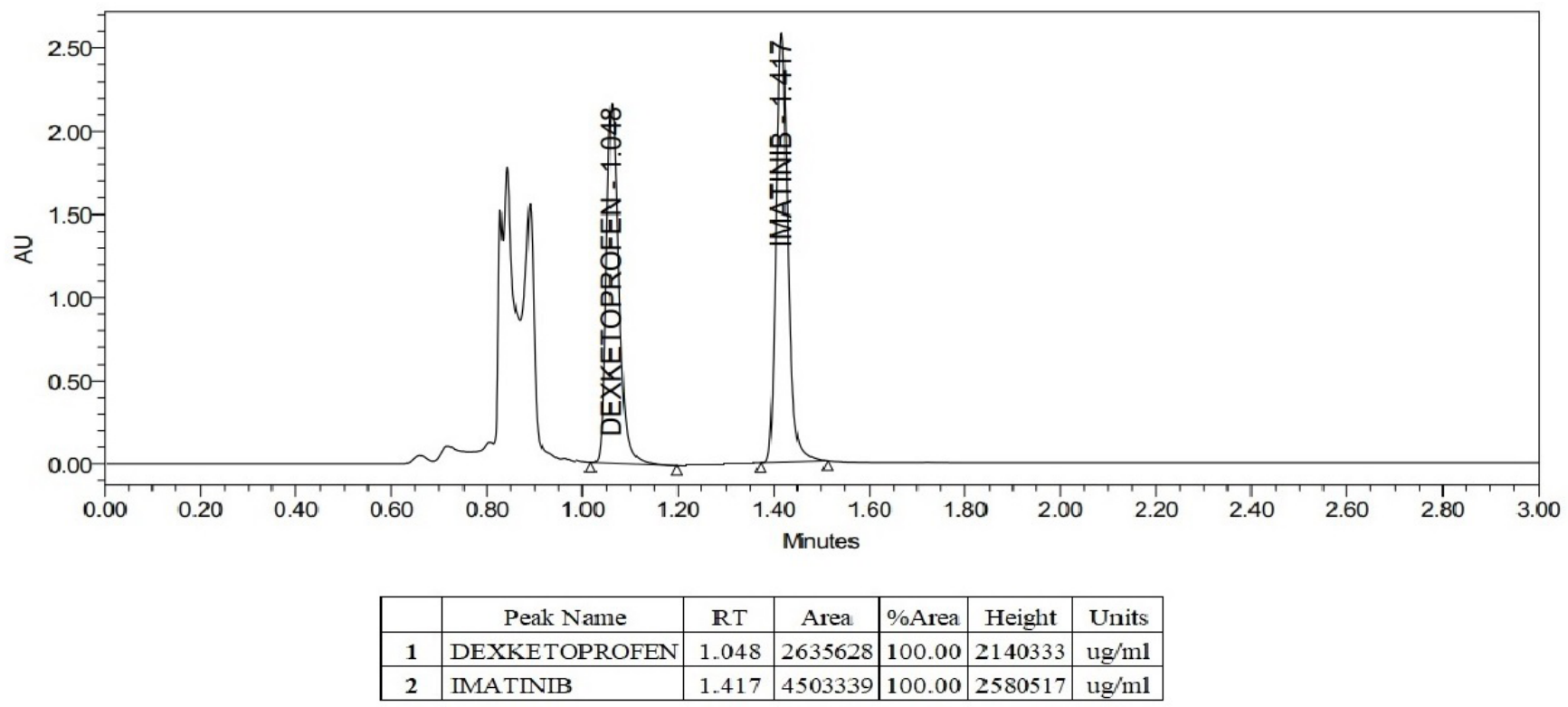

FIGURE 8 - UPLC chromatogram of dexketoprofen trometamol and imatinib mesylate in DMEM. 
TABLE VII - P-values of remained DEX and IMA in solutions for robustness

\begin{tabular}{|c|c|c|c|c|c|c|c|c|c|}
\hline & \multicolumn{3}{|c|}{ Distilled water } & \multicolumn{3}{|c|}{ pH 7.4 Phosphate Buffer } & \multicolumn{3}{|c|}{ DMEM } \\
\hline & $4^{\circ} \mathrm{C}$ & $25^{\circ} \mathrm{C}$ & $37^{\circ} \mathrm{C}$ & $4^{\circ} \mathrm{C}$ & $25^{\circ} \mathrm{C}$ & $37^{\circ} \mathrm{C}$ & $4^{\circ} \mathrm{C}$ & $25^{\circ} \mathrm{C}$ & $37^{\circ} \mathrm{C}$ \\
\hline IMA & 0.909 & 0.076 & 0.065 & 0.391 & 0.391 & 0.103 & 0.423 & 0.085 & 0.126 \\
\hline DEX & 0.215 & 0.080 & 0.066 & 0.441 & 0.431 & 0.080 & 0.415 & 0.078 & 0.113 \\
\hline
\end{tabular}

$\mathrm{P}>0.05$, level of significance.

LOD is the lowest quantity of analyte in a sample that can be detected, but not certainly quantified while LOQ is the lowest quantity of analyte in a sample in which the quantity of analyte can be determined as an absolute value. Both can be calculated based on the standard deviation of the response and the slope (ICH, 2005). The results are presented in Table VIII and Table IX.

The validation parameters were obtained from various repeated studies (number of replicates shown in brackets for each result). The results were given as mean \pm standard deviation, and the calibration curve of the analytical method was obtained considering concentrations versus peak areas. A quite high correlation was obtained (r2:0.999 for both of samples in each medium) with the concentration range of $0.05-20 \mu \mathrm{g} / \mathrm{mL}$ in the three different media for DEX and IMA. The concentrations of $10 \mu \mathrm{g} / \mathrm{mL}$ DEX and IMA were used to test the accuracy of the method, for which $80 \%$ and $120 \%$ concentrations were prepared, and all samples were analyzed. The amounts of DEX and IMA in these solutions were determined using the proposed method, and the accuracy of the methods was found to be within the acceptable range. System precision was calculated also for the ten samples, while intermediate precision was determined by analyzing the samples on different days. The precision values were found to be suitable. A simultaneous analysis of IMA and DEX showed that the method is specific for both drug substances, in that the peaks of the analytes were observed at different retention times, and these peaks were far away from the peak of the solvent on the chromatogram. In the robustness studies, the samples were kept at various temperatures and compared with the initial values, and no significant difference was observed between the groups $(\mathrm{P}>0.05)$. The LOQ and LOD for DEX and IMA were found to be suitable. For all parameters, RSD values were lower than $2 \%$.
TABLE VIII - Limit of detection and limit of quantitation values for imatinib mesylate

\begin{tabular}{lccc}
\hline & $\begin{array}{c}\text { Distilled } \\
\text { water }\end{array}$ & $\begin{array}{c}\text { pH 7.4 } \\
\text { Phosphate } \\
\text { Buffer }\end{array}$ & DMEM \\
\hline LOQ $(\mu \mathrm{g} / \mathrm{mL})$ & 0.014 & 0.037 & 0.012 \\
LOD $(\mu \mathrm{g} / \mathrm{mL})$ & 0.005 & 0.012 & 0.004 \\
\hline
\end{tabular}

DMEM is Dulbecco's Modified Eagle Medium. LOQ is limit of quantification. LOD is limit of detection.

TABLE IX - Limit of detection and limit of quantitation values for dexketoprofen trometamol

\begin{tabular}{lccc}
\hline & $\begin{array}{c}\text { Distilled } \\
\text { water }\end{array}$ & $\begin{array}{c}\text { pH 7.4 } \\
\text { Phosphate } \\
\text { Buffer }\end{array}$ & DMEM \\
\hline LOQ $(\mu \mathrm{g} / \mathrm{mL})$ & 0.006 & 0.013 & 0.038 \\
LOD $(\mu \mathrm{g} / \mathrm{mL})$ & 0.002 & 0.004 & 0.013 \\
\hline
\end{tabular}

DMEM is Dulbecco's Modified Eagle Medium. LOQ is limit of quantification. LOD is limit of detection.

\section{CONCLUSION}

A rapid, isocratic UPLC method was developed for quantitative simultaneous analysis of DEX and IMA. The method was found to be precise, accurate, linear and fast. This method may be useful for researchers interested in carrying out in vitro and ex vivo studies, 
such as quantification, dissolution, stability and cell culture studies, with IMA, DEX, or a combination of the two.

\section{ACKNOWLEDGMENTS}

Some data were from the part of $\mathrm{PhD}$ thesis completed at Gazi University, Faculty of Pharmacy, Department of Pharmaceutical Technology, 06330 Ankara, Turkey and this work was supported by the Scientific and Technological Research Council of Turkey (TÜB TAK, No. 213M675).

\section{REFERENCES}

Antil P, Kaushik D, Jain G, Srinivas KS, Indu KT. UPLC method for simultaneous determination of valsartan and hydrochlorothiazide in drug products. J Chromat Separation Techniq. 2013;4(5):1-5.

Archana K, Vikas P. Development and validation of reversed phase high performance liquid chromatographic method for estimation of dexketoprofen trometamol in bulk and tablet dosage form. AJPCT. 2013;1(4):395-400.

Atari-Hajipirloo S, Nikanfar S, Heydari A, Noori F, Kheradmand F. The effect of celecoxib and its combination with imatinib on human HT-29 colorectal cancer cells: Involvement of COX-2, Caspase-3, VEGF and NF- $\kappa \mathbf{B}$ genes expression. Cell Mol Biol. 2016;62(2):68-74.

Chandrasekharan NV. Dexketoprofen. USA: Brigham Young University; 2007;1-4.

Cohen MH, Moses ML, Pazdur R. Gleevec ${ }^{\mathrm{TM}}$ for the treatment of chronic myelogenous leukemia: U.S. food and drug administration regulatory mechanisms, accelerated approval, and orphan drug status. Oncologist. 2002;7(5):390-392.

Dannenberg AJ, Altorki NK, Boyle JO, Dang C, Howe LR, Weksler BB, et al. Cyclo-oxygenase 2:a pharmacological target for the prevention of cancer. Lancet Oncol. 2001;2:544-551.

FDA Consum. FDA approves Gleevec for leukemia treatment. FDA Cons Mag. 2001;35(4):1.

FDA Consum. FDA approves new drug for gastrointestinal stromal tumors. Clin J Oncol Nurs. 2002;6(3):124-125.

Gowda R, Kardos G, Sharma A, Singh S, Robertson GP. Nanoparticle-based celecoxib and plumbagin for the synergistic treatment of melanoma. Mol Cancer Ther. 2017;16(3):440-452.
Gumustas M, Kurbanoglu S, Uslu B, Ozkan SA. UPLC versus HPLC on drug analysis: advantageous, applications and their validation parameters. Chromatographia. 2013;76:1365-1427.

Herrero JF, Romero-Sandoval EA, Gaitan G, Mazario J. Antinociception and the new COX inhibitors: research approaches and clinical perspectives. CNS Drug Reviews. 2003;9(3):227-252.

ICH.Q2(R1). Validation of analytical procedures: text and methodology", ICH Harmonised Tripartite Guideline. of Technical Requirements for Registration of Pharmaceuticals for Human Use, Chicago, USA; 2005.

Iqbal N, Iqbal N. Imatinib: a break through of targeted therapy in cancer. Chemother Res Pract. 2014;2014:357027.

Ivanovic D, Medenica M, Jancic B, Malenovic A. Reversedphase liquid chromatography analysis of imatinib mesylate and impurity product in Glivec ${ }^{\circledR}$ capsules. J Chromatogr B. 2004;800(1-2):253-258.

lbasm1-Tamer S. Development and validation of an ultra performance liquid chromatography method for the determination of dexketoprofen trometamol, salicylic acid and diclofenac sodium. Turk J Pharm Sci. 2017;14(1):1-8.

Kumari S, Ram B, Kumar D, Ranote S, Chauhan GS. Nanoparticles of oxidized-cellulose synthesized by green method. Mat Sc Energy Technol. 2018;1(1):22-28.

Liu B, Yan S, Qu L, Zhu J. Celecoxib enhances anticancer effect of cisplatin and induces anoikis in osteosarcoma via PI3K/Akt pathway. Cancer Cell Int. 2017;17(1): 1-8.

Ma S, Xu Y, Shou M. Characterization of imatinib metabolites in rat and human liver microsomes: differentiation of hydroxylation from N-oxidation by liquid chromatography/ atmospheric pressure chemical ionization mass spectrometry. Rapid Commun Mass Spectrom. 2009;23(10):1446-1450.

Miao ZL, Deng YJ, Du HY, Suo XB, Wang XY, Wang X, et al. Preparation of a liposomal delivery system and its in vitro release of rapamycin. Exp Ther Med. 2015;9(3):941-946.

Miranda HF, Noriega V, Sierralta F, Prieto JC. Interaction between dexibuprofen and dexketoprofen in the orofacial formalin test in mice. Pharmacol Biochem Behav. 2011;97(3):423-427.

Mohammed SI, Craig BA, Mutsaers AJ, Glickman NW, Snyder PW, deGortari AE, et al. Effects of the cyclooxygenase inhibitor, piroxicam, in combination with chemotherapy on tumor response, apoptosis, and angiogenesis in a canine model of human invasive urinary bladder cancer. Mol Cancer Ther. 2003;2(2):183-188. 
Moreno JM, Wojnicz A, Steegman JL, Cano-Abad MF, Ruiz-Nuño A. Imatinib assay by high performance liquid chromatography in tandem mass spectrometry with solidphase extraction in human plasma. Biomed Chromatogr. 2013;27(4):502-508.

Mulla TS, Rao JR, Yadav SS, Bharekar VV, Rajput MP. Development and Validation of Hplc Method for Simultaneous Quantitation of Paracetamol and Dexketoprofen Trometamol in Bulk Drug and Formulation. Pharmacie Globale International Journal of Comprehensive Pharmacy. 2011;7(9):1-4

Mutlu-Ağardan NB, Değim Z, Yılmaz Ş, Altıntaş L, Topal T. The effectiveness of raloxifene loaded liposomes and cochleates in breast cancer therapy. AAPS PharmSciTech. 2016;17(4):968-977.

Nageswari A, Reddy KKVSR, Mukkanti K. Stabilityindicating UPLC method for determination of imatinib mesylate and their degradation products in active pharmaceutical ingredient and pharmaceutical dosage forms. J Pharm Biomed Anal. 2012;66:109-115.

Nováková L, Solichová D, Solich P. Advantages of ultra performance liquid chromatography over high-performance liquid chromatography:comparison of different analytical approaches during analysis of diclofenac gel. J Sep Sci. 2006;29(16):2433-2443.

Novartis Pharmaceutical Corporation. Gleevec-imatinib mesylate tablet. Highlights of prescribing information. New Jersey, USA; 2017.
Pan YY, Xu SP, Jia XY, Xu HQ, Zhang Y, Rui LX, et al. Combination of cyclooxygenase-2 inhibitor and doxorubicin increases the growth inhibition and apoptosis in human hepatocellular carcinoma cells. Exp Oncol. 2007;29(1):23-29.

Reed RB, Ladner DA, Higgins CP, Westerhoff P, Ranville JF. Solubility of nano-zinc oxide in environmentally and biologically important matrices. Environ Toxicol Chem. 2012;31(1):93-99.

Rezende VM, Rivellis AJ, Gomes MM, Dörr FA, Novaes MMY, Nardinelli L, Costa ALL, Chamone DAF, Bendit I. Determination of serum levels of imatinib mesylate in patients with chronic myeloid leukemia: validation and application of a new analytical method to monitor treatment compliance. Rev Bras Hematol Hemoter. 2013;35(2):103-108.

Sahoo NK, Sahu M, Alagarsamy V, Srividya B, Sahoo CK. Validation of assay indicating method development of imatinib in bulk and its capsule dosage form by liquid chromatography. Ann Chromatogr Separat Tech. 2015;1(2):1010-1014.

Singh S. Liposome encapsulation of doxorubicin and celecoxib in combination inhibits progression of human skin cancer cells. (T-NANO 2014 Abstracts). Int J Nanomedicine. 2018;13:11-13.

Yue PF, Lu WY, Zhang ZZ, Yuan HL, Zhu WF, Zheng Q, et al. The study on the entrapment efficiency and in vitro release of puerarin submicron emulsion. AAPS PharmSciTech. 2009;10(2):376-383.

Received for publication on $25^{\text {th }}$ July 2018 Accepted for publication on $12^{\text {th }}$ December 2018 